\title{
Portraiture in Indian Miniature Paintings
}

\author{
Sourabh Ghosh \\ Research Scholar, Chitkara Business School and Sr. Vice President, Kotak Mahindra Bank \\ Ltd., Chandigarh, India. E-mail: sourabhgh@yahoo.co.in
}

\begin{abstract}
The art of miniature painting in India traces its origin to the Buddhist manuscript Illustrations of the Pala period in Nepal and Eastern part of India in the $8^{\text {th }}$ to $11^{\text {th }}$ century. The Jain manuscripts in Gujrat and Rajasthan, as early as $11^{\text {th }}$ century, also point towards a practice of such illustrations. These manuscripts, apart from portraying religious literature, also covered wide ranging topics such as medicine, astrology, etc. They were profusely illustrated, and were mostly inscribed on palm leaves. Apart from serving as important treatises, they were widely used as gifts during royal marriages and accessions. However, the Mughal Rule in India brought a certain degree of sophistication, refinement and finesse to this form of art. Under successive Mughal Rulers, the art of miniature painting reached its zenith. While Babur and Humayun, who were great lovers of art and literature, could not build proper ateliers during their reigns due to their frequent military campaigns and conflicts, they were responsible for bringing to India two versatile artists, Abdus Samad and Mir Sayed Ali from the Safavid Persian Court-whose works would have significant impact on the art of miniature paintings in the Mughal Courts. Humayun's successors Akbar, Jahangir and Shah Jahan built some of the most significant ateliers under their rules, and some of the preeminent miniature artists like Basavan, Manohar, Bichitar, Ustad Mansur, Balchand and Murad flourished under their patronage. Some very significant works like Baburnama, Akbarnama, Razamnama, etc. were also commissioned by the early Mughal Emperors. With the decline of the Mughal Empire, the miniature painting scene shifted to the Rajput Courts in Rajasthan and the Hill States in Northern India. Various important Schools of painting -like the Mewar, Marwar, Jaipur, Hadoti, Kangra, Basholi, and Garhwal - Schools, to name a few, started flourishing under their respective rulers. While the Mughal influence still prevailed, yet each school had its own distinctive characteristic and feature. The subjects of these paintings and manuscripts ranged from religious literature, court scenes, royal processions, flora and fauna, textiles, jewelry to elaborate equestrian and hunting scenes. However, the most riveting and captivating depictions were in the form of elaborate and brilliant portraits of the rulers, their nobles and courtiers, which not only throw light on their magnificent reigns, but also open a window to the culture, tradition and practices of those times. This essay makes an attempt to study the fine art of portraiture in miniature paintings in the various Mughal, Provincial and Rajput Courts to bring out their historical and cultural significance.
\end{abstract}

Key Words: Miniature Painting, Mughal School, Rajput School, Portraits, Hill Schools, History, Culture, Art.

\section{Portraiture in Malwa and Central India with its Centers at Mandu and Bundelkhand}

Some of the earliest known examples of Indian miniature Portraiture emerge from the Central Indian region of Malwa, which is otherwise well known for the illustrated Jain manuscript Kalapsutra.

(c) AesthetixMS 2018. This Open Access article is published under a Creative Commons Attribution Non-Commercial 4.0 International License (http://creativecommons.org/licenses/by-nc/4.o/), which permits non-commercial re-use, distribution, and reproduction in any medium, provided the original work is properly cited. For citation use the DOI. For commercial re-use, please contact editor@chitrolekha.com 


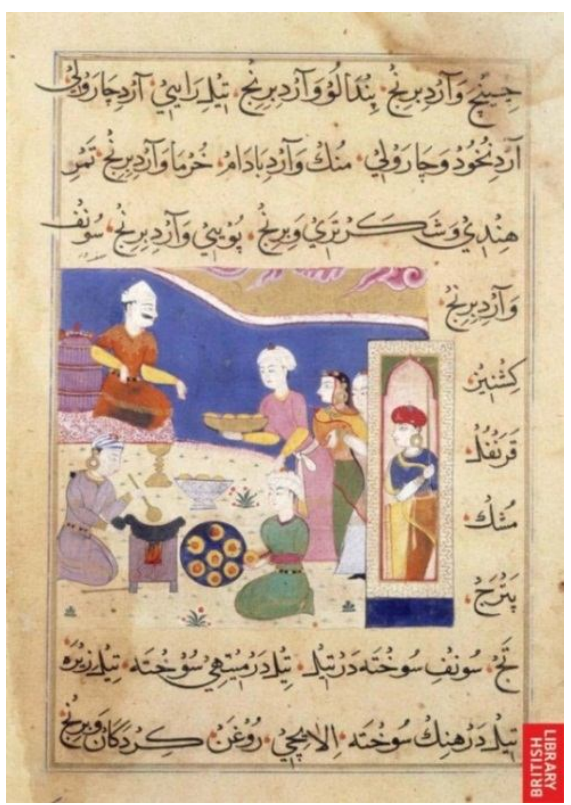

Fig. 1: A page from the Nimatnama. Late $15^{\text {th }}$ and Early $16^{\text {th }}$ Century. Mandu. Source: The India Office, British Library at London.

It is here in the courts of Ghiyas-ud-din Khilji and his son Nasir-ud-Din, that a profusely illustrated manuscript -Nimatnama was written. The Nimatnama, or the Book of Pleasures, is a treasure trove of delicacies. Written in Persian in the Nashk script, the book consists of fifty illustrations (Refer Fig. 1), with the Sultan as the central figure. Apart from detailed recipes of various delicacies, the illustrations also show detailed landscapes and portraiture. Painted in the Shirazi style, most probably by a Persian artist in the Mandu Court, the paintings depict the Sultan and the other characters, mostly women, with long-drawn eyes, colourful clothes and with headgear matching those in Persian paintings. The figures are mostly devoid of ornamentation and elaborate jewelry.

This art of manuscript painting, which commenced under the Khilji Sultans, was to develop into full blown portraiture in the courts of Datia and Raghogarh in Malwa.

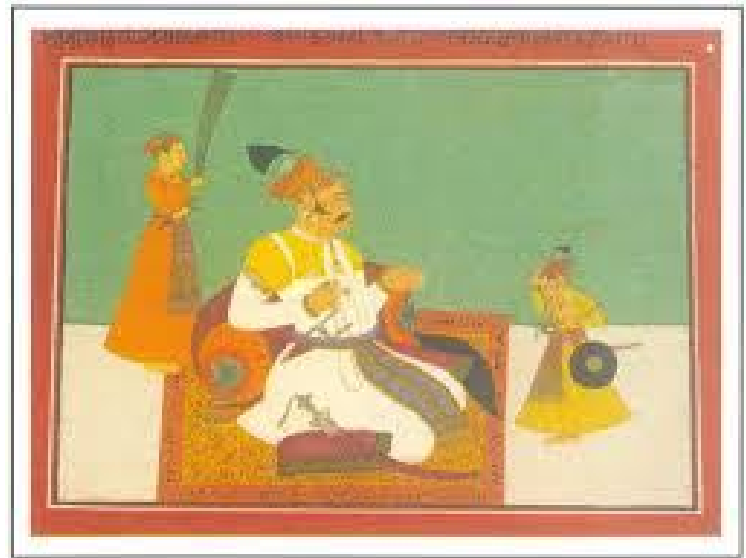

Fig. 2: Seated Portrait of Maharaja of Raghogarh with an attendant and Young Prince.

1720 ca. Source: The National Museum at New Delhi 
The Raghogarh atelier had expert portrait artists, and though with a strong Rajput touch, the degree of craftsmanship was of the highest order. The Raghogarh portraits show the rulers in simple but bright colours, with the size of the figures depicting their relative importance or stature. (Refer Fig 2). Quite like their Rajasthani counterparts, there are attendants holding a 'morchal' (a hand-held fan) and standing behind the ruler. The backgrounds in the portraits are generally devoid of any landscape. Apart from court portraits of the ruling elite, the Raghogarh artists also produced a large number of equestrian portraits.

\section{Mughal Portraiture}

The Mughals ruled for four hundred years, and shaped one of the finest schools of miniature painting over these years. The successive rulers promoted art, literature and music in their courts. As mentioned earlier, Babur and Humayun could not supervise the setting up of a stable and fullfledged atelier in their courts. It was with the accession of Humayun's son Jalal-ud-din Mohammad Akbar that the art of miniature painting blossomed into a force to reckon with. The Persian Masters in the Mughal court had a major influence on the style, especially on the art of portraiture. Radiant faces, with vivid expressions, rugged and green landscapes, with flowing rivers, added a great amount of energy and life to the gesturing figures. Emphasis was laid on facial expressions and tones.

Figures from Persian myths, and use of bright yellow, green and red gave the paintings and portraits an animated look. Exquisite calligraphy and drawings of flora and fauna on the borders was the trademark of the Mughal Atelier. It is said, that at one point of time, more than hundred miniature artists practiced their art in the court of Akbar. It was here that a lot many collaborative works were undertaken. While the "Ustad" (master) would execute the final "chehra kushai" or "chehra numai" (drawing the faces) of the portraits, two or three apprentices would initially prepare the sketch and initial colouring ("amal”).

The collaborative work among artists continued even during the reign of Jahangir, and some famous works were executed by a collaboration of court artists. One such work is the seated portrait of Prince Salim. (Refer Fig. 3). While the portrait has been drawn by Manohar, the ornamentation and decorative works on the throne and borders have been executed by Mansur.

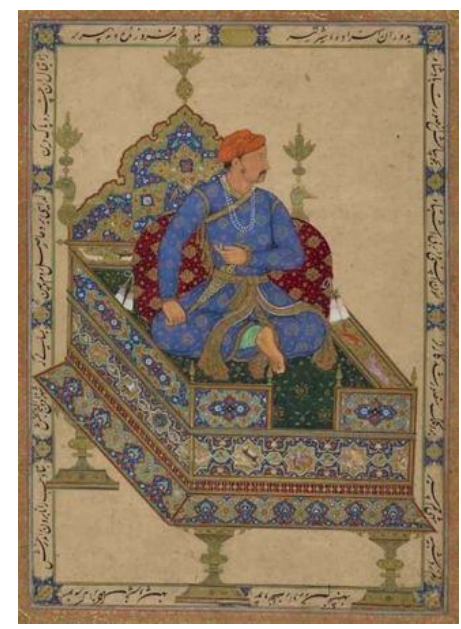

Figure 3: Prince Salim (Jahangir) seated on his throne. Artist: Manohar (Portraiture) and Mansur (Ornamentation on the Throne). Mughal School. 1600-01 ca. Source: Russian Academy of Sciences at St. Petersburg. 
Another such joint work was the Portrait of Jahangir holding the orb and Jesus Christ. The work shows Jahangir in the upper panel, whereas Christ is depicted in the lower panel with the cross. The panel is richly decorated on all sides by beautiful flowers and leaves. The Portrait of Jahangir is the work of Hashim, and that of Jesus has been illustrated by Abul Hasan. (Refer Fig.4).

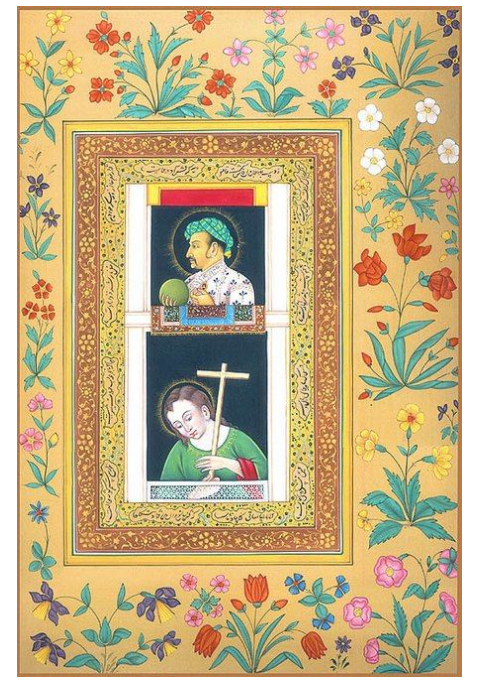

Fig. 4: Emperor Jahangir with the Orb, with Jesus Christ. By Hashim and Abul Hasan. 1618-2o ca Source: Chester Beatty Library.

The illustration in Fig 4, and the one in Fig $\mathbf{5}$ below, show a marked European influence which had crept into Mughal Portraiture since the latter half of Akbar's reign when the Jesuit Missionaries first visited his court. So marked was the confluence of cultures, that even the famous Dutch Artist Rembrandt was greatly influenced by the Mughal School. In fact, between the years ${ }^{6}{ }_{54}{ }^{-}$ 56 , he drew a series of twenty five paintings in the Mughal style, most of which were the portraits of Shah Jahan and the nobles in his court.

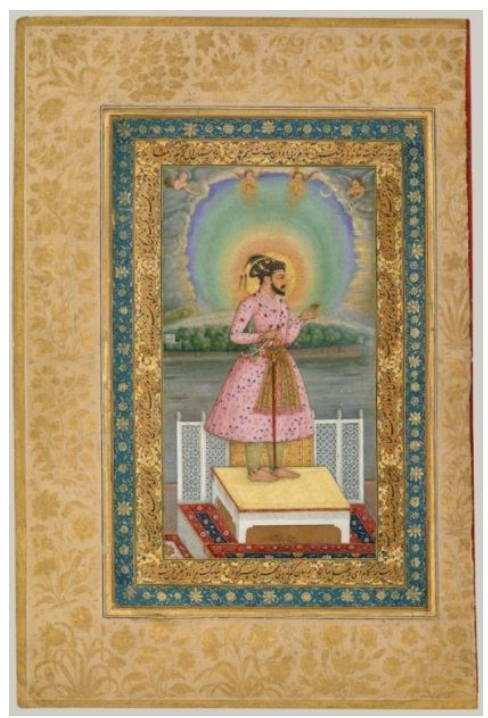

Fig 5: Standing Portrait of Shah Jahan with a Pendant containing his Portrait. Painted by Chitarman for a Folio of the Shah Jahan Album. Dated 1627-28 ca. Ink, watercolor and gold on paper. Source: The Metropolitan Museum of Art, New York. 
Fig 5 shows Shah Jahan in his full royal glory. Chitarman paints the emperor, who is standing on a pedestal, with his imperial regalia, with his exquisitely designed Angarkha, rich jewelry, and his royal turban. The halo around his appearance and the small angelic figures at the top of the painting symbolize the European influence in this work. The exquisitely decorated borders, and the calligraphy in it, are a key feature of the works during the times of Jahangir and Shah Jahan. Another prominent feature of the portraits of those times was the depiction of landscapes and buildings in the background, often in muted colours, so as to create a sense of distance and space. This was in contrast to the early Mughal works, where the landscape would tend to merge and co-exist with the figures in the frame. This particular work is part of a 'Murrakka' (patch-work album) which gained prominence in India during the reign of Jahangir and continued during the reign of Shah Jahan. Jahangir was himself a great collector of art, and he is said to have had a vast collection of portraits, paintings and murrakkas in his royal collection.

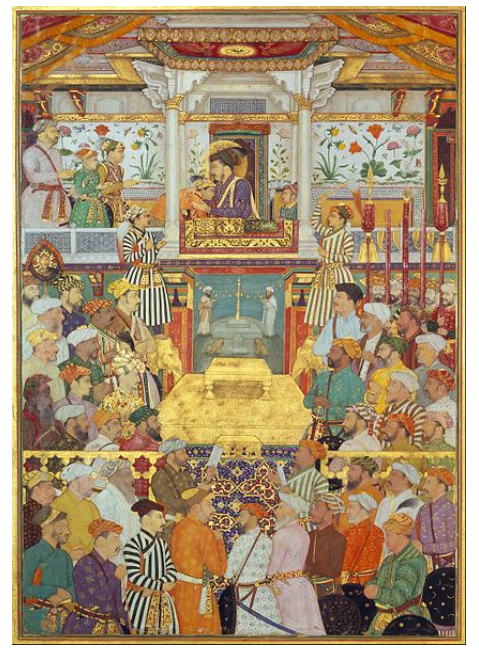

Fig. 6: An illustrated folio from the Padshahnama. By Bichitr. Early to mid - $17^{\text {th }}$ century. Source: The Royal Collection Trust.

A recurrent and prominent theme in Mughal portraiture was the court scene. This brought out the best in the artists, and their craftsmanship. In Fig. 6, the court artist Bichitr portrays the coronation court of Shah Jahan. The Emperor is seen greeting his three sons, who are accompanied by Asaf Khan. The individual facial portraiture of each person in the painting, along with the creation of space and levels, are one of the chefs-d'oeuvre of the prevalent Mughal technique. The rich floral motifs, and the gold work, add certain richness to the work. This version of the Padshahnama (Book of Kings), of which this illustration is a part, clearly chronicles Shah Jahan's rule, and also lists the names and designations of all the nobles who are depicted in this painting, thus providing valuable information on the hierarchy and composition of the royal court.

Under the austere rule of Aurangzeb, the Mughal Portraiture showed a marked decline, and a majority of the court artists shifted base to the various courts in Rajputana, Punjab Hills, and Provincial Courts at Awadh, Murshidabad and Deccan. Though Mohammad Shah's reign witnessed a faint whiff of revival of Mughal portraiture, with the major themes centered around court scenes, harems, mendicants and 'sadhus,' and royal processions, but the earlier skill, energy and craftsmanship went missing in the portraits of those times.

\section{Portraiture in the Rajput Schools}

Though the art of manuscript illumination and miniature paintings in Rajasthan date back to earlier times, portraiture in Rajput miniatures started with the exodus of Mughal artists to various 
Rajasthan courts from the early seventeenth century. Rajput painting developed in various courts and kingdoms, giving rise to various schools of painting, each with its unique style. Almost all prominent Rajput courts had their own atelier, and the tradition of miniature paintings in these courts were handed down from one generation to the other. While around ten main centres or schools were in existence in Rajasthan, there were quite a few schools which gained prominence in the smaller principalities. Some of the prominent schools were named after the courts from which they originated- like Jaipur, Mewar, Marwar, Kota/Bundi, Bikaner, and Kishangarh.

While the Mughal portraits had a certain degree of subtlety and finesse in them, the Rajput painters depended more on the folk elements in their executions. The decorated borders, a trade mark of Mughal artists, slowly vanished in the Rajput ateliers. These paintings where more elaborate, with each school having its own distinctive facial category which ran through almost all portraits that were drawn. A big differentiator was the headgear, which stood out prominently as a symbol of the particular school. The initial paintings in the Rajput courts had a marked Mughal influence, and a few schools like Bikaner kept the Mughal tradition alive. The depiction of the ruler in broad flowing 'angarkha' (robes) or 'jama' and with heavy bodies, sometimes took away the sense of dimension in the portraits. Most of the Rajput portraits depicted the male rulers and their courtiers, with almost no female portraiture on record.

The use of colours was most vibrant, the lines less distinctive, and the use of motifs and traditional folk symbols more prominent. The flat landscape became quite prominent, and the depiction of local architecture was pronounced. While a large majority of Mughal portraits contained the names of the artists who executed them, hardly a handful of Rajput paintings bear the name of the creators.

From the initial Mughal influence, to the plump Mewar portraits, to the intricate hunting scenes of Bundi/Kota, to the delicate and angular facial expressions at Kishangarh, Rajput painting moved to heavily ornamental, architectural and somewhat rigid style of the Amer School. The Mughal influence in the Jodhpur (Mewar) court and the later portraits with large foreheads and eyes and somewhat curving nose, manifested itself at the Bikaner court too.

Rajput portraiture received generous patronage under successive Mewar rulers Raj Singh I, Jai Singh, Amar Singh II, Sangram Singh II and Jagat Singh II in the Seventeenth Century and early Eighteenth Century. Here too, quite a few paintings have been discovered where two or more artists have collaborated. Rao Raja Ram Singh II (1827-66) at Kota, Raja Raj Singh (1706-48), his son Raja Sawant Singh (1748-57) at Kishangarh, Raja Mansingh (1592-1614), Raja Jai Singh (1621-67) and Sawai Jai Singh (1699-1743) at Amer, Raja Udai Singh (1583-95), Raja Gaj Singh (1619-38), Raja Abhay Singh (1729-49) and Thakat Singh (1843-73) at Marwar (Jodhpur), Maharaja Karan Singh (1631-74), Raja Anoop Singh (1669-98) at Bikaner were major patrons who presided over large ateliers. 


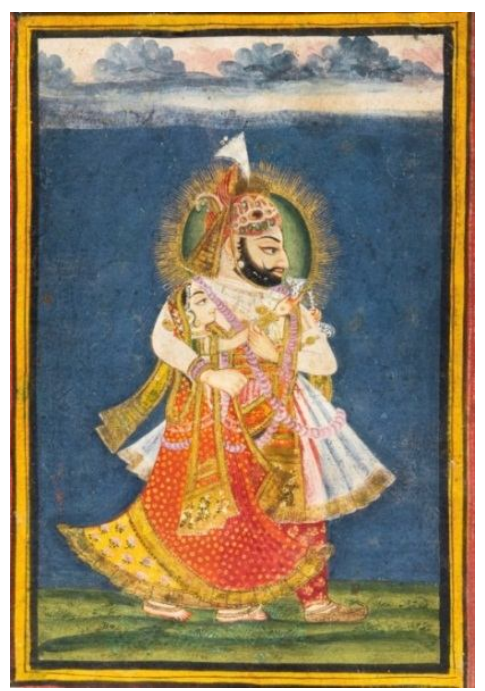

Fig. 7: Maharaja Bhim Singh with consort, Devgarh, Mewar, 1810 ca. Gouache with gold on paper with Devanagari inscription on outer border. Source: Sotheby's: Art of Imperial India Auction, o8 October, 2014 .

In Fig. 7, Maharaja Bhim Singh of Mewar is seen with his consort. Attributed to the followers of court artist Chokha, the king is shown here with a halo around his head, and with rich jewelry. The landscape is uniform and flat and a few clouds are shown in the background. The size of the figures depicts their relative position and importance, which is so very typical of the Rajput Schools.

The Rajputs, being a strong warrior class, depict numerous hunting scenes and equestrian portraits of their rulers and nobles decked up for battle or processions. Horses are worshipped in Rajputana, and the tales of their valour go hand in hand with those of their rulers. The horses are adorned with decorated trappings, and a long retinue is seen following the horse. Refer Fig. 7.

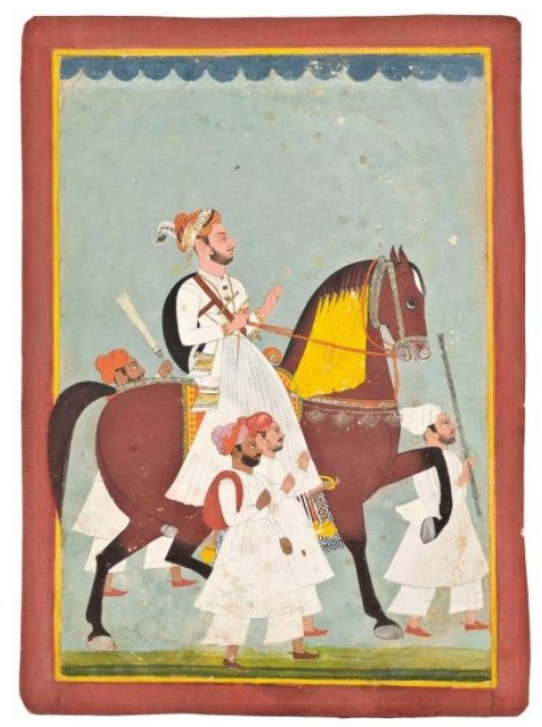

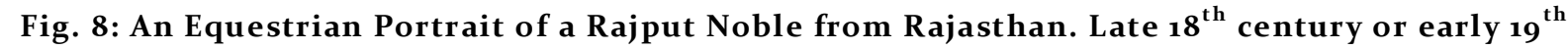
century. Pigments on paper, amplified by gold. Source: Lot No. 2: Christie's Looking East: Art of India and Western Asia Auction. 
Almost all prominent schools, especially those in Kota and Bundi, depicted large royal processions, and hunting scenes, which show the rulers seated on decorated elephants or horses, with a large retinue of followers and courtiers in attendance.

The Rajput portraits also depict vivid illustrations of the rulers participating in religious festivals and ceremonies. Various portraits of the time show them celebrating the festivals of Holi, Diwali and Teej. In Fig. 9, Maharaja Man Singh of Marwar is shown enjoying the festival of Holi with a 'Bhagtan' (a class of entertainers in Rajasthan). The king is shown here on a terrace with decorated railings and a jharokha or window. The flowing Jama and rich ornaments of the ruler, and the bright red lehenga of the Bhagtan, portray a sense of contrast to the white background which is dispersed with the Holi colours.

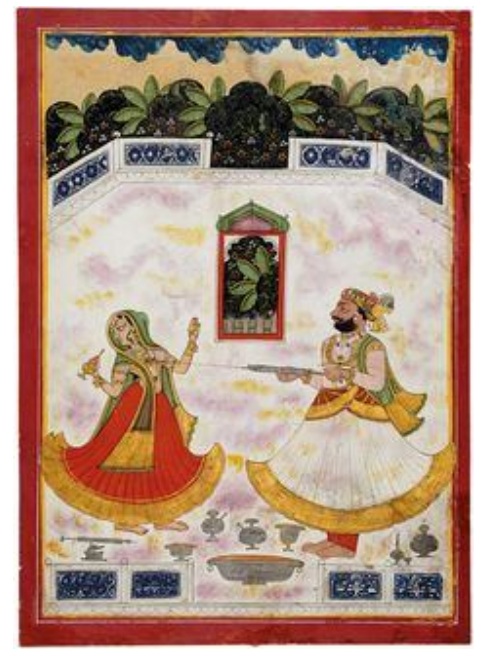

Fig. 9: A Raja celebrating the festival of Holi. Marwar. 1840 ca. Source: The Anil Relia Collection.

Effect of European art in the latter half of the nineteenth century made the portraits more realistic, and quite a few portraits show influence of photography in the later Rajput portraiture.

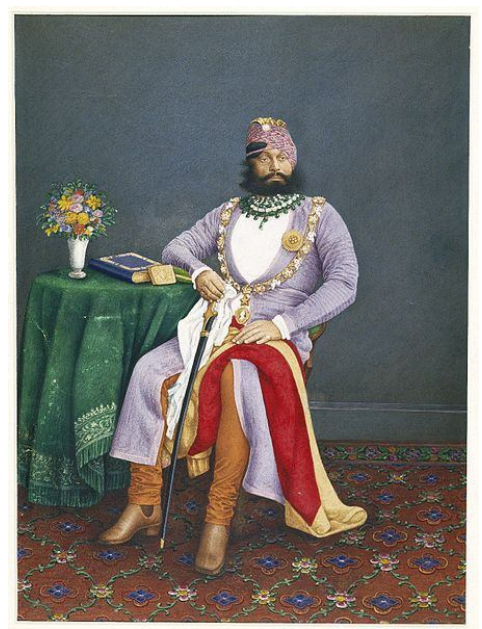

Fig. 10: Sitting Portrait of Maharaja Jaswant Singh II, Marwar. 1880 ca. Attributed to the artist Narsingh. Source: The Brooklyn Museum.

Fig. 10 depicts Maharaja Jaswant Singh of Mewar in a seated position with a robe and bejeweled necklace. His high heeled boots, the carpet in the foreground, and the realistic and plain background point towards the marked European influence on the court artists. 


\section{Portraiture in the Hill States}

With the decline of Mughal patronage, a sizeable number of artists shifted their base to the Punjab Hills. They were to find benefaction in the predominantly Rajput Courts of the various local rulers. In the seventeenth and the eighteenth centuries, these courts were to witness some exquisite craftsmanship.

The paintings in the Hills Schools were strongly influenced by the fluid and precise lines of Mughal painting. Combined with inspiration from the classical religious texts and the surrounding greenery and landscape, the Hill Paintings made a significant mark stylistically.

The main schools of miniature painting where situated at Basholi, Chamba, Jammu, Jasrota, Mankot, Nurpur, Guler, Mandi, Kangra, Kulu and Garhwal.

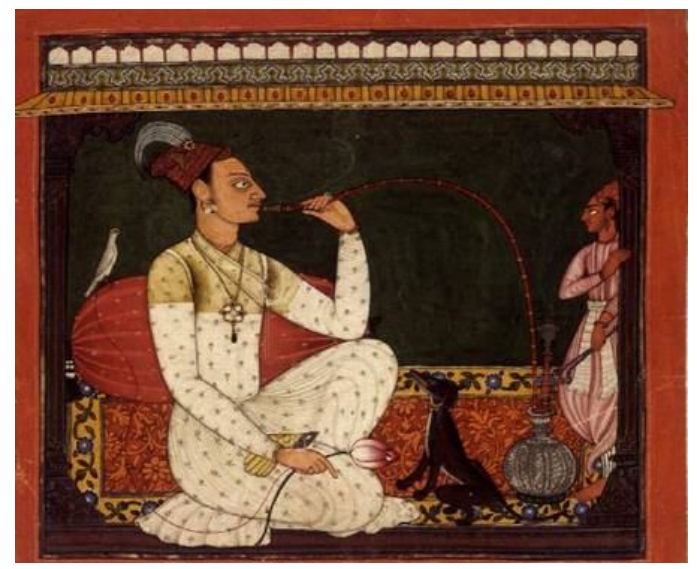

Fig: 11: Raja Medini Pal. Basholi 1730 ca. Source: The National Museum, New Delhi.

Some of the earliest portraits came from the Hill State of Basholi, where strong colours, slim features, wide foreheads, elongated eyes and angular noses are the striking characteristics. (Fig.11). Again the ruler or nobles are drawn in decreasing size of their relative importance in the courts. The hookah was a trademark in quite a few Hill portraits, and the background is devoid of any landscape, unlike the Mughal and Rajput Portraits.

The Hill portraits in the $18^{\text {th }}$ century, which reached a high level of maturity under the rulers of Guler and Jasrota, were painted by the family of Pandit Seu. The artist, along with his sons Manaku and Nainsukh, who served under Raja Raj Singh and Raja Dalip Singh of Guler and Raja Balwant Singh of Jasrota. Their portraits, especially those by Nainsukh, were marked by subtle lines, muted colours and plain backgrounds. The 'chitera' or the artist would often be a part of the court, and would observe the king and the nobles very intently. The portraiture was detailed, yet simple, and the facial features of the subject would be drawn to perfection. 


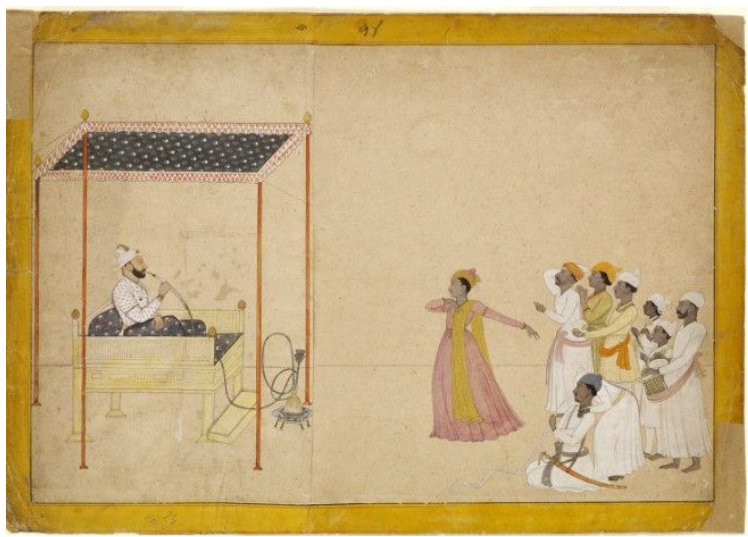

Fig. 12: Raja Balwant Singh of Jasrota. 1750 ca. Nainsukh. Watercolour, heightened with gold on paper. Source: Victoria \& Albert Museum.

Fig. 12 depicts a seated portrait of Raja Balwant Singh by the famous artist Nainsukh. The king is seen enjoying a musical and dance performance in his chamber while smoking a 'hookah'. The preciseness of the human figures is extraordinary, and the use of muted colours, with the free use of white, confers it with an almost Sufi and divine sensitivity. The plain background brings out the action and movement in the painting. Though precise and simple, the Hill portraiture lacked the picturesque landscape and the ornamented borders which are otherwise the hallmark of the paintings with religious subjects in the Hills.

The Sikh School which thrived under the patronage of Maharaja Ranjit Singh had various centres including Lahore, Amritsar and Patiala. In the beginning of the 19th Century, when Ranjit Singh subjugated the king of Kangra, quite a few of the Hill artists shifted their allegiance to the Sikh court. Most of the paintings revolved around the lives of the Guru Nanak Dev and the other Sikh Gurus.

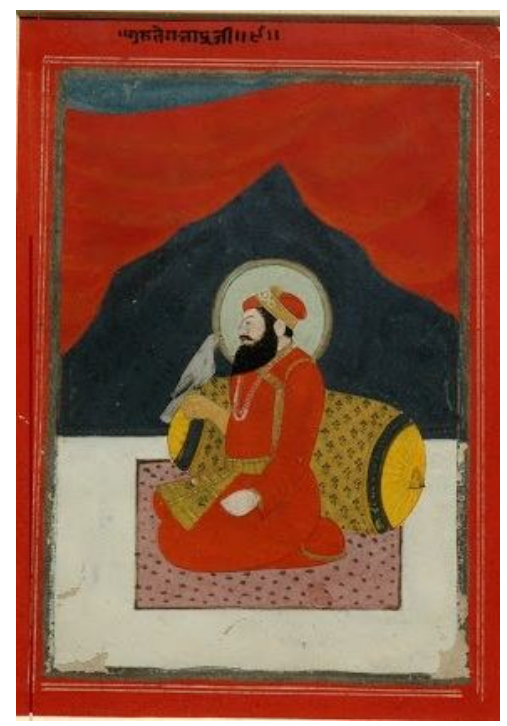

Fig. 13: Sitting Portrait of Guru Teg Bahadur. Late $19^{\text {th }}$ Century. Sikh School. Source: Academy of Fine Arts and Literature.

The portraits of Maharaja Ranjit Singh and the other Sikh rulers had a marked European and Hill School influence, with a certain degree of formality. The decorated borders, and rich landscape 
was replaced by Sufi figures of the Gurus in long flowing robes, halo around their countenance and plain backgrounds. Refer Fig. 13.

\section{The Deccan School and its Portraiture}

The Deccan Kingdoms of Golconda, Ahmadnagar, Hyderabad and Bijapur produced Schools of Painting which had a strong mixture of Persian, Turkish and Mughal styles. The later portraits also had a significant European influence. The use of soft colours and precise outlines, a certain vigour and grace, with slightly conical 'patkas' or headgear, were the hallmark of Deccani portraiture.

An amalgamation of styles, the Vijayanagar influence in the early Deccan portraits bestows on them a slightly elongated facial expression. Application of gold and silver, and green and brown backgrounds added a certain depth and profundity to the figures. Like in the Mughal ateliers, a lot of emphasis was placed on realistic depiction of the rulers, their nobles and courtiers. Attention was paid to the symphonic use and mixing of colours. The figures were vibrant and seem to be always on the move, and the landscape was filled with exquisitely designed flora and fauna, rivers and rocks.

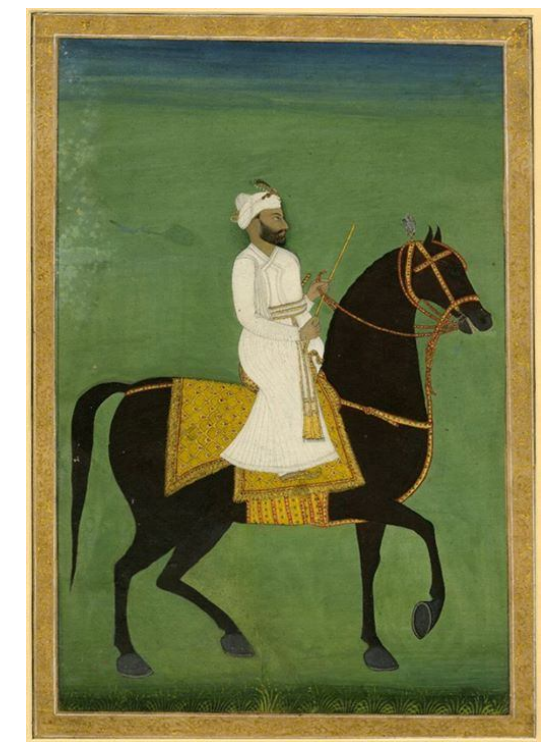

Fig. 14. Equestrian Portrait of a Noble. Deccan School. Late $18^{\text {th }}$ Century. Source: The British Museum.

In Fig. 14, a Noble is seen riding a horse which, with its raised legs, gives a sense of movement and energy to the figure. The sharp chiseled and slightly conical facial features, is further bestowed a sense of gravity by the use of white against a pale green background. The plain background, devoid of landscape, brings the focus on the central figure. The preciseness of the lines, and the perfection in drawing the figures, brings about an almost lifelike vigor to the painting. The portraits of Sultan Murtaza Nizam Shah of Ahmednagar, Ibrahim Adil Shah and Mohammad Adil Shah at Bijapur are striking in their execution and composition. 


\section{Conclusion}

The art of miniature painting in general and portraiture in particular, takes us to the magical world of the medieval rulers and theirs courts. They not only open an important vista for understanding and studying the customs and traditions of the times, but also throw light on the prevalent artistic practices. It pays a glowing tribute to the all-embracing and multi ethnic culture of our country, and its festivals and rites. Through these wonderful pieces of imagery on paper, the sometimes known, but the mostly unknown artist, paints a kaleidoscopic image of the past and brings it alive for us to cherish.

\section{References}

Ahluwalia, Roda. (2008). Rajput Painting. British Museum Press.

Basholi. (1730 ca). Raja Medini Pal (painting). New Delhi: The National Museum.

Bichitr. (16oo ca). An illustrated folio from the Padshahnama (manuscript illustration). London: The Royal Collection Trust.

Chakraverty, Anjan. (1996). Indian Miniature Painting. (Edition 2005). India: Roli Books.

Chitarman. (1627-28 ca). Standing Portrait of Shah Jahan with a Pendant containing his Portrait (painting). New York: The Metropolitan Museum of Art.

Deccan School. (1900 ca). Equestrian Portrait of a Noble (painting). London: The British Muse um.

Devgarh, Mewar. (1810 ca). Maharaja Bhim Singh with consort (painting). Art of Imperial India Auction. Sotheby's.

Goswamy, B. N. and Fischer, Eberhard. (2009). Pahari Masters: Court Painters of Northern India. India: Niyogi Books.

Hashim, and Hasan, Abul. (1618-2o ca). Emperor Jahangir with the Orb, with Jesus Christ (painting). Dublin: Chester Beatty Library.

Mandu. (160o ca). A page from the Nimatnama (manuscript illustration). London: The India Office, British Library.

Manohar and Mansur. (1600-01 ca). Prince Salim (Jahangir) seated on his throne (painting). St. Petersburg: Russian Academy of Sciences.

Marwar School. (1840 ca). Maharaja Celebrating the Festival of Holi (painting). Ahmedabad: Anil Relia Collection.

Marwar School (170o ca). An Equestrian Portrait of a Rajput Noble (painting). Looking East: The Art of India and Western Asia Auction. Christies.

Nainsukh. (1750 ca). Raja Balwant Singh of Jasrota (painting). London: Victoria \& Albert Museum.

Narsingh (188o ca). Sitting Portrait of Maharaja Jaswant Singh II, Marwar (painting). New York: The Brooklyn Museum.

Raghogarh. (1720 ca). Seated Portrait of Maharaja of Raghogarh with an attendant and Young Prince (painting). New Delhi: The National Museum.

Soni, Sonika and Relia, Anil. (2016). The Indian Portrait- VIII: Rajputana Nayak. Ahmedbad: Archer.

Sikh School. (18oo ca). A Sitting Portrait of Guru Teg Bahadur (painting). New Delhi: Academy of Fine Arts and Literature.

Sourabh Ghosh is a Research Scholar in the Chitkara Business School, Chitkara University, Chandigarh. He is also a Senior Vice President with Kotak Mahindra Bank. His areas of interest are handwritten manuscripts and miniature paintings. He has been an avid collector and enthusiast for the last two decades, and has arranged quite a few exhibitions and art shows across the country. His area of research is Art as an Investment. 